\title{
Structures and Photoelectric Properties of Ce and Co Doped CulnTe 2 Semiconductor
}

\author{
Shuai LI ${ }^{1, a}$, Yong-Quan GUO ${ }^{1, b, *}$ \\ ${ }^{1}$ School of Energy Power and Mechanical Engineering, North China Electric Power University, \\ Beijing 102206, China \\ aq15202525@126.com, byqguo@necpu.edu.cn \\ ${ }^{*}$ Corresponding author
}

Keyword: Culn ${ }_{1-x-y} \mathrm{Ce}_{x} \mathrm{Co}_{y} \mathrm{Te}_{2}$, Chalcopyrite Structure, Semiconductor, Band Gap.

\begin{abstract}
The samples of $\mathrm{CuIn}_{1-\mathrm{x}-\mathrm{y}} \mathrm{Ce}_{\mathrm{x}} \mathrm{Co}_{\mathrm{y}} \mathrm{Te}_{2}$ were successfully synthesized by vacuum arc-melting method. The structure and optical and electric properties of Ce and Co doped $\mathrm{CuInTe}_{2}$ have been investigated using Powder X-ray diffraction(XRD), scanning electron microscopy(SEM), ultraviolet and visible spectrophotometer (UV-vis), respectively. The result shows that the Ce and Co doped CIT has the chalcopyrite structure with a space group of I-42d.The lattice parameters shows no obvious regulation with the increase of Co content. The SEM morphologies indicate that the grain sizes tend to decrease with the increase of Co content in $\mathrm{CuIn}_{1-\mathrm{x}-\mathrm{y}} \mathrm{Ce}_{\mathrm{x}} \mathrm{Co}_{\mathrm{y}} \mathrm{Te}_{2}$ semiconductor. The band gap $\mathrm{E}_{\mathrm{g}}$ also increases from $1.17 \mathrm{eV}$ to $1.27 \mathrm{eV}$. It reveals that the increase of Co content is helpful for the absorption of spectra with special frequencies.
\end{abstract}

\section{Introduction}

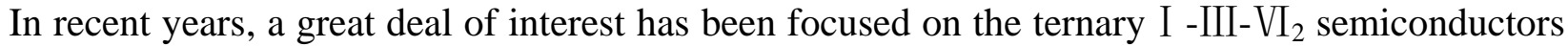
with chalcopyrite structure ${ }^{[1]}$. $\mathrm{CuInSe}_{2}$ solid solution with Ga substitution for In, and $\mathrm{S}$ substitution for Se, commonly referred to as $\mathrm{Cu}(\mathrm{In}, \mathrm{Ga})(\mathrm{Se}, \mathrm{S})_{2}(\mathrm{CIGS})^{[2,3]}$, is a leading candidate material of solar cells because of its high photoelectric transformation efficiency of $20.3 \%{ }^{[4]}$. CuInTe $\mathrm{C}_{2}$ is one of the I - III- $\mathrm{VI}_{2}$ compound which has been widely investigated in the world. Because CuInTe $\mathrm{C}_{2}$ (CIT) film shows an excellent photoelectric property and has the potential application as one of the competent absorber materials in the photovoltaic devices ${ }^{[5]}$. Many studies on $\mathrm{CuInTe}_{2}$ have been done in order to understand its electronic, electrical and optical properties ${ }^{[6]}$. Also adding a complementary composition to semiconductor sensitizers can give to an ability of physical and optical properties, which is improved in a broader absorption range and enhanced charge separation, leading to yield larger photovoltaic performances ${ }^{[7]}$.

In this paper, the Ce and Co doped $\mathrm{CuInTe}_{2}$ compounds are prepared to analysis its structure, SEM morphologies, optical and electric properties which aimed to prove the efficiency of photoelectric conversion.

\section{Experiment Method}

The metallic compounds in this experiment with structural formula of $\mathrm{CuIn}_{1-\mathrm{x}-\mathrm{y}} \mathrm{Ce}_{\mathrm{x}} \mathrm{Co}_{\mathrm{y}} \mathrm{Te}_{2}$ $(\mathrm{x}=0.1, \mathrm{y}=0,0.1,0.2$ and 0.3$)$, which the raw materials $(\mathrm{Cu}, \mathrm{In}, \mathrm{Ce}, \mathrm{Co}, \mathrm{Te})$ purity were higher than $99.99 \%$, were synthesized by vacuum arc-melting method. Considering the volatileness of tellurium, an extra $10 \%$ of Te was added for compensating the weight losses during the melting. To ensure the homogeneity, each sample was turned upside and down for 3 times. The phase structure were checked using an X-ray diffractometer (Rigaku G/max 2500, using CuKa1 radiation with $\lambda=1.54056 \AA ; 40 \mathrm{~m} \mathrm{~A}, 200 \mathrm{kV}$ ). The field emission scanning electron microscopy (FE-SEM JSM-7001F) equipped were used to investigate the surface morphologies. The absorption rate dependence of wavelength for $\mathrm{CuIn}_{1-\mathrm{x}-\mathrm{y}} \mathrm{Ce}_{\mathrm{x}} \mathrm{Co}_{\mathrm{y}} \mathrm{Te}_{2}(\mathrm{x}=0.1, \mathrm{y}=0,0.1$ and 0.3$)$ was obtained on a Shimadzu 2450UV-Vis spectrophotometer. 


\section{Results}

\section{XRD Analysis}

The X-ray Diffraction (XRD) of $\mathrm{CuIn}_{1-\mathrm{x}-\mathrm{y}} \mathrm{Ce}_{\mathrm{x}} \mathrm{Co}_{\mathrm{y}} \mathrm{Te}_{2}(\mathrm{x}=0.1, \mathrm{y}=0,0.1,0.2$ and 0.3$)$ are shown in Fig.1.The diffraction peaks could be indexed as a tetragonal structure according to the result of TREOR program. The planar indices follow the extinction laws of the chalcopyrite $\mathrm{CuInTe}_{2}$ with a space group of I-42d.The diffraction characteristic peaks of (112), (220), (312), (316) and (424) planes in the chalcopyrite structure are observed for $\mathrm{CuIn}_{1-\mathrm{x}-\mathrm{y}} \mathrm{Ce}_{\mathrm{x}} \mathrm{Co}_{\mathrm{y}} \mathrm{Te}_{2}$ samples. The lattice parameter of the samples also be calculated and the results are revealed in Fig.2 (a)-(b). The lattice parameters and volumes are corresponding to $\mathrm{a}=6.1901 \AA-6.1951 \AA, \mathrm{c}=12.3217 \AA-12.4293 \AA$. We can see that lattice show fluctuation phenomenon which may be the influence of the impure phase $\mathrm{CoTe}_{2}$ and $\mathrm{CeO}_{2}$.

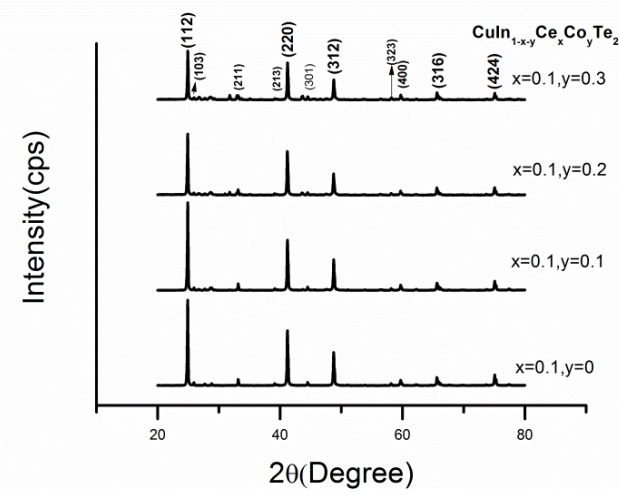

Fig.1 XRD Patterns of $\mathrm{CuIn}_{1-\mathrm{x}-\mathrm{y}} \mathrm{Ce}_{\mathrm{x}} \mathrm{Co}_{\mathrm{y}} \mathrm{Te}_{2}$ Samples

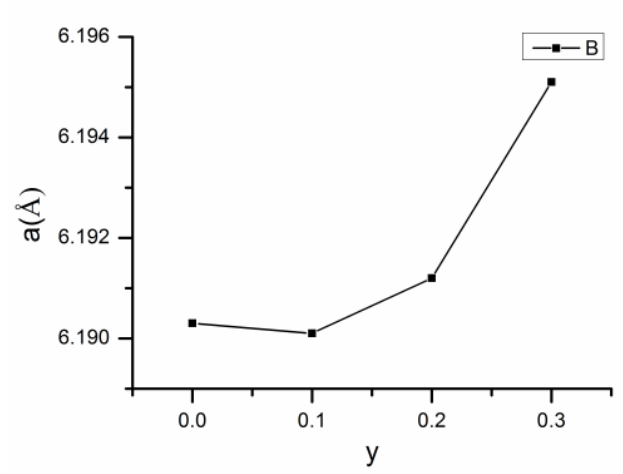

(a)

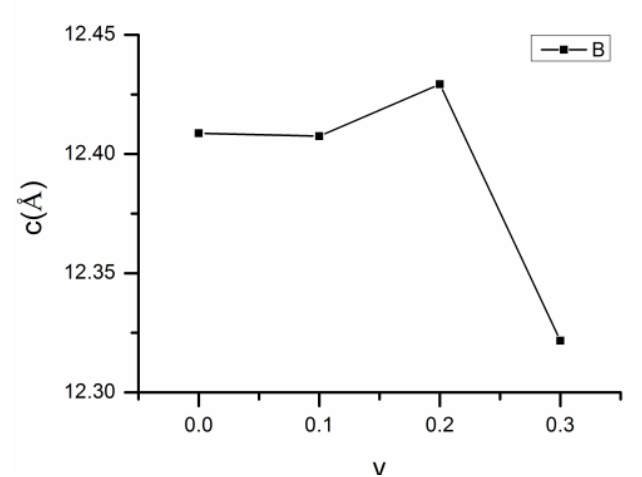

(b)

Fig.2 Latter Parameters a (a) and c (b) Dependence of Co Contents

\section{SEM Analysis}

The Cerium and Cobalt content dependences of SEM morphologies for $\mathrm{CuIn}_{1-\mathrm{x}-\mathrm{y}} \mathrm{Ce}_{\mathrm{x}} \mathrm{Co}_{\mathrm{y}} \mathrm{Te}_{2}$ $(\mathrm{x}=0.1$ and $\mathrm{y}=0,0.1,0.3)$ are shown in Fig.4 (a)-(c), respectively. It can be seen in the three follow picture that the growths of the grain is inhomogeneous with the distribution of both lager bulks and small pieces. The grain sizes tend to decrease with the increase of Co content in $\mathrm{CuIn} 1-\mathrm{x}-\mathrm{y} \mathrm{Ce}_{\mathrm{x}} \mathrm{Co}_{\mathrm{y}} \mathrm{Te}_{2}$ semiconductor. The morphologies on the grain surfaces show that the evolutions of the grains from initial columnar crystal to larger granularity with cuspidal particals and the finally layer structures. 


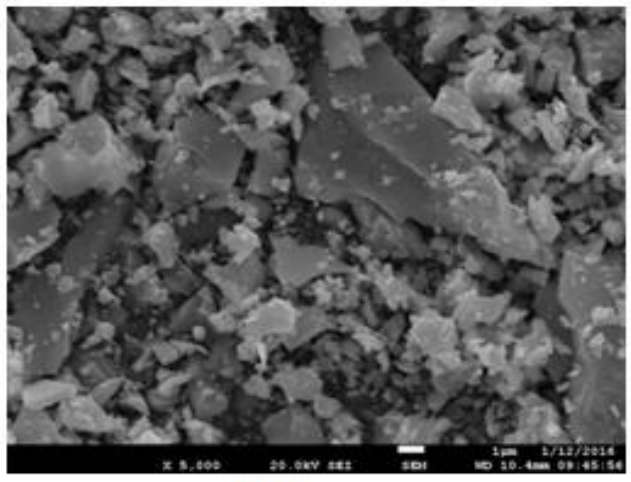

(a) $y=0$

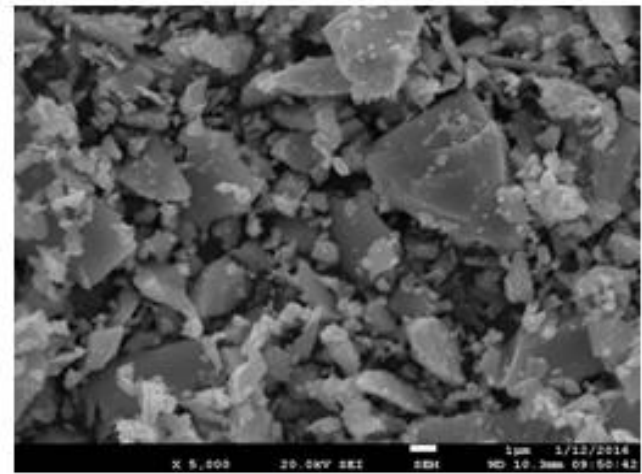

(b) $y=0.1$

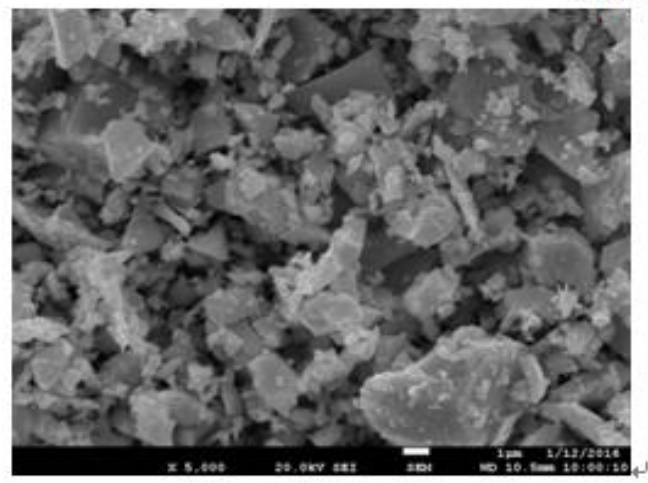

(c) $y=0.3$

Fig.3 SEM Images of $\mathrm{CuIn}_{0.9-\mathrm{y}} \mathrm{Ce}_{0.1} \mathrm{Co}_{\mathrm{y}} \mathrm{Te}_{2}(\mathrm{y}=0-0.3)$ Powders

\section{Absorption Performance}

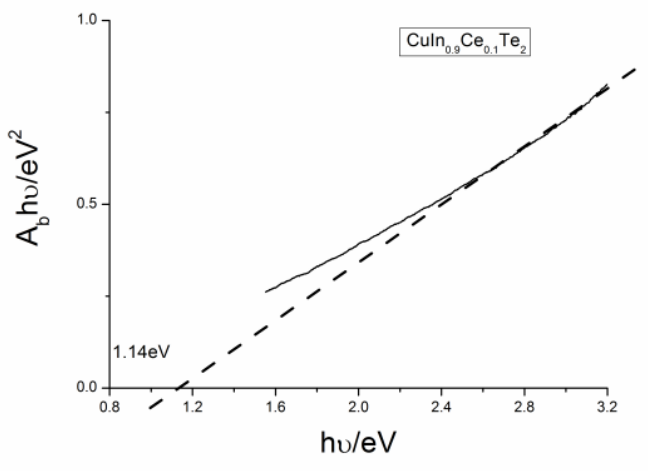

(a)

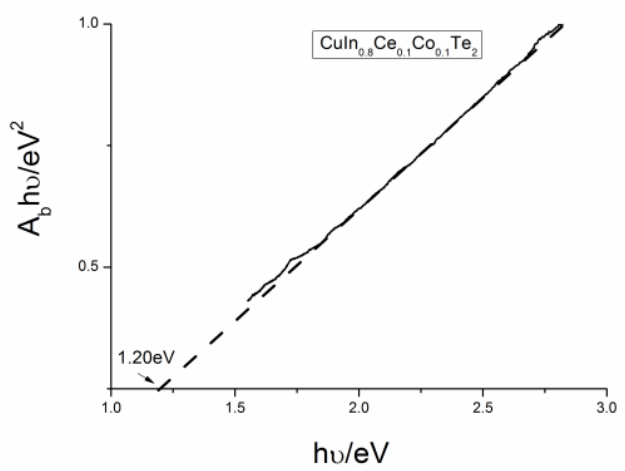

(b)

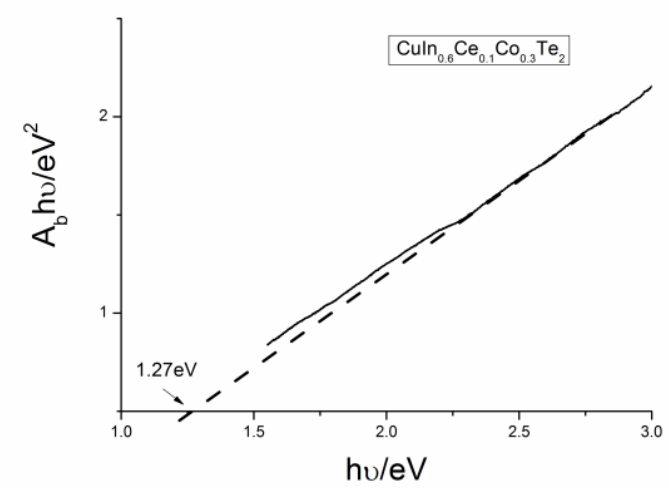

(c)

Fig.4 UV-V is Spectra of $\mathrm{CuIn}_{0.9} \mathrm{Ce}_{0.1} \mathrm{Te}_{2}, \mathrm{CuIn}_{0.8} \mathrm{Ce}_{0.1} \mathrm{Co}_{0.1} \mathrm{Te}_{2}$ and $\mathrm{CuIn}{ }_{0.6} \mathrm{Ce}_{0.1} \mathrm{Co}_{0.3} \mathrm{Te}_{2}$ Powders 
The absorption spectra of $\mathrm{CuIn}_{0.9-\mathrm{y}} \mathrm{Ce}_{0.1} \mathrm{Co}_{\mathrm{y}} \mathrm{Te}_{2}$ recorded by UV-vis spectrophotometer at room temperature with the wavelength between $400 \mathrm{~nm}-800 \mathrm{~nm}$. And the curve is shown in Fig.4.

The direct band gap $\left(\mathrm{E}_{\mathrm{g}}\right)$ can be calculated by the equation $(1)^{[8]}$ :

$$
\mathrm{A}(\mathrm{h} v)=\mathrm{A} / \mathrm{h} v\left(\mathrm{~h} v-\mathrm{E}_{\mathrm{g}}\right)^{\mathrm{p}}
$$

where $\alpha$ is the absorption coefficient, $\mathrm{A}$ is a constant and $\mathrm{p}$ depends on the nature of transitions, $\mathrm{p}=1 / 2$ for direct transitions and $\mathrm{p}=2$ for indirect transitions. The picture of $(\alpha h v)^{2}$ versus $h v$ is shown in Fig.4.From the extrapolation of the curve to $(\alpha h v)^{2}=0$, the energy gap of the $\mathrm{CuIn}_{0.9} \mathrm{Ce}_{0.1} \mathrm{Co}_{\mathrm{y}} \mathrm{Te}_{2}$ $(\mathrm{x}=0.1$ and $\mathrm{y}=0,0.1,0.3)$ is calculated to be $1.17 \mathrm{eV}$ for $\mathrm{CuIn}{ }_{0.9} \mathrm{Ce}_{0.1} \mathrm{Te}_{2}, 1.20 \mathrm{eV}$ for $\mathrm{CuIn}_{0.8} \mathrm{Ce}_{0.1} \mathrm{Co}_{0.1} \mathrm{Te}_{2}$ and $1.27 \mathrm{eV}$ for $\mathrm{CuIn}_{0.6} \mathrm{Ce}_{0.1} \mathrm{Co}_{0.3} \mathrm{Te}_{2}$, respectively. It can be seen that the energy band gap increases due to the increase of Co content.

\section{Conclusions}

Cerium and Cobalt doped $\mathrm{CuInTe}_{2}$ powders were successfully synthesized by vacuum arc-melting. XRD shows that $\mathrm{CuIn}_{1-\mathrm{x}-\mathrm{y}} \mathrm{Ce}_{\mathrm{x}} \mathrm{Co}_{\mathrm{y}} \mathrm{Te}_{2}(\mathrm{x}=0.1, \mathrm{y}=0,0.1,0.2$ and 0.3$)$ have a tetragonal chalcopyrite structure and the space group is I-42d.The lattice parameter shows fluctuation phenomenon because of the influence of the impure phase. SEM morphologies of the samples indicate that the grain sizes tend to decrease with the increase of Co content. UV-Vis measurements demonstrate that Increase of Cobalt content can raise the energy band gap of the samples. It is more suitable for the absorbed layer material solar spectra than $\mathrm{CuInTe}_{2}$.

\section{Acknowledgement}

This study is supported by the National Natural Science Foundation of China (Grant no.11274110).

\section{References}

[1] Xiaomeng Nie, Yongquan Guo, Effects of europium substitution for in on structure and photoelectric properties of Cu In1 xEuxTe2. 2015.

[2] Chen D S, Yang J, Xu F, Zhou P H, Du H W, Shi J W, Yu Z S and Zhang Y H 2013 Chin. Phys. B 22018801.

[3] Li W, Zhao Y M, Liu X J, Ao J P and Sun Y 2011 Chin. Phys. B 20068102.

[4] Jackson P, Hariskos D, Lotter E, Paetel S, Wuerz R, Menner R, Wischmann W and Powalla M 2011 Progress in Photovoltaics: Research and Applications 19894.

[5] Fu li, Guo yongquan, Synthesis, structure, optical, and electric properties of Ce-doped $\mathrm{CuInTe}_{2}$ compound. 2014.

[6] M. Mobarak, H.T. Shaban: Materials Chemistry and Physics. 147 (2014), p. 439-442.

[7] Patamaporn Termsaithong, Auttasit Tubtimtae, Boron-doped CuInTe 2 semiconductor-sensitized liquid-junction solar cells. 2014.

[8] M. Boustani, K. E1 Assali, T. Bekkay, A. Khiara: Solar Energy Materials and Solar Cells, 45 (1997) p. 369-376. 